\title{
Piallina tethydis gen. et sp.nov. (Foraminiferida) from the Triassic (Carnian) of the Kocaeli Peninsula, Turkey
}

\author{
R.RETTORI \\ Dipartimento di Scienze della Terra \\ dell'Università degli Studi di Perugia, \\ 06100 Perugia, Italy.
}

\author{
L. ZANINETTI \\ Département de Geologie et Paléontologie, et \\ Département de Zoologie, \\ Université de Genève, 1211 Gèneve 4, \\ Switzerland. \\ D. VACHARD \\ UFR des Sciences de la Terre (Laboratoire de \\ Paleobiologie), URA 1365 du CNRS (Bâtiment \\ SN5), 59655 Villeneuve d'Ascq Cédex, France.
}

\author{
R. MARTINI \\ Département de Géologie et Paléontologie, \\ Université de Genève, \\ 1211 Genève 4, Switzerland.
}

\begin{abstract}
A new genus, Piallina Rettori \& Zaninetti (type-species Piallina tethydis Rettori \& Zaninetti sp.nov.), is recorded from the Upper Triassic (Carnian) of the Kocaeli Peninsula (Turkey). The new Family, the Piallinidae is also introduced. J. Micropalaeontol. 12 (2): 170-174, December 1993.
\end{abstract}

\section{INTRODUCTION}

During a revision of foraminiferal material from the Kocaeli Peninsula (Gebze area, Turkey) (Fig. 1), deposited by Zeki Dager in the Department of Geology and Palaeontology, University of Geneva, a new genus, Piallina (type-species: P. tethydis Rettori \& Zaninetti sp.nov.), has been discovered; it is formally described herein. Dager (1978a, b) had studied and partially illustrated the foraminifera, which cover several Triassic stratigraphic sequences in the Kocaeli Peninsula.

The new genus has been recorded in a thin section from Carnian limestones of the Tepeköy A sequence, Tepe Member, Tepeköy Formation (Dager, 1978b).

The lithostratigraphic succession of the Triassic Tepeköy A sequence is composed of (from the bottom to top):

- light grey thick bedded limestones and dolomites (Latest Scythian-Early Anisian);

- light grey thin bedded nodular limestone, containing a rich assemblage of ammonites and conodonts (Anisian);

- nodular reddish fossiliferous (ammonites, daonellas) limestone of "Ammonitico rosso" facies (Late Anisian-Early Ladinian);

- green-grey marls with clayey limestone interbedded (Carnian, based on the occurrence of Halobia);

- brownish siliciclastic sandstones intercalated with marls and limestones.

Piallina tethydis gen. et sp.nov. occurs in the clayey limestone beds intercalated within marls containing Halobia ( $H$. bithynica); the sequence is referred by several authors to the Carnian (Assereto, 1972, 1974; Özdemir et al., 1973; Nicora \& Premoli Silva, 1976; Nicora, 1977; Dager, 1977, $1978 \mathrm{a}, \mathrm{b}$ ), to the Carnian excluding the Early part (Zaninetti \& Dager, 1978) or to the Upper Carnian (Yurttas-Özdemir, 1971, 1972, 1973; Gedik, 1975).

\section{SYSTEMATIC DESCRIPTION}

Superfamily Verneuilinacea Cushman, 1911

Family Piallinidae Rettori \& Zaninetti fam.nov.

Genus Piallina Rettori \& Zaninetti gen.nov.

Type-species Piallina tethydis Rettori \& Zaninetti gen. et sp.nov.

Derivation of name. The new genus is named in honour of Professor Giampaolo Pialli, University of Perugia, for his knowledge of the Tethyan geology and for his constant encouragement and interest in our research.

Description. Test free, elongate, rounded in section. Consisting of a short early stage in the form of a low trochoid (or streptospiral?) coil; second stage triserial, short, followed by a trochospiral stage, slightly contorted, with an indefinite number of chambers per whorl (probably not more than five) which reduces to three, possibly two, chambers per whorl in the final stage. Undivided chambers subangular in shape with distinct rounded angles and indistinct sutures. Wall agglutinated, simple, noncanaliculate, with smooth surface. Aperture rounded, interiomarginal, characterized by an extension of wall within the chamber lumen in direction of preceding chamber.

Stratigraphical/Geographical distribution. Upper Triassic (Carnian, Upper Carnian?) of Hungary (Transdanubian Central Range) and Turkey (Kocaeli Peninsula); Carnian? of China (Yushu Region of Qinghai).

Piallina tethydis Rettori \& Zaninetti gen. et sp.nov. (Pl. 1, figs. 1-12, 13?)

?1987 Gaudryinella clavuliniformis Trifonova; Oravecz-Scheffer: 99, pl. 33, fig. 11.

1987 Gaudryinella cf. kotlensis Trifonova; Oravecz-Scheffer: pl. 43, fig. 10.

1990 Valoulina? sp; He \& Wang, in He: 70, pl. 2, figs. 15, 16, 20. 


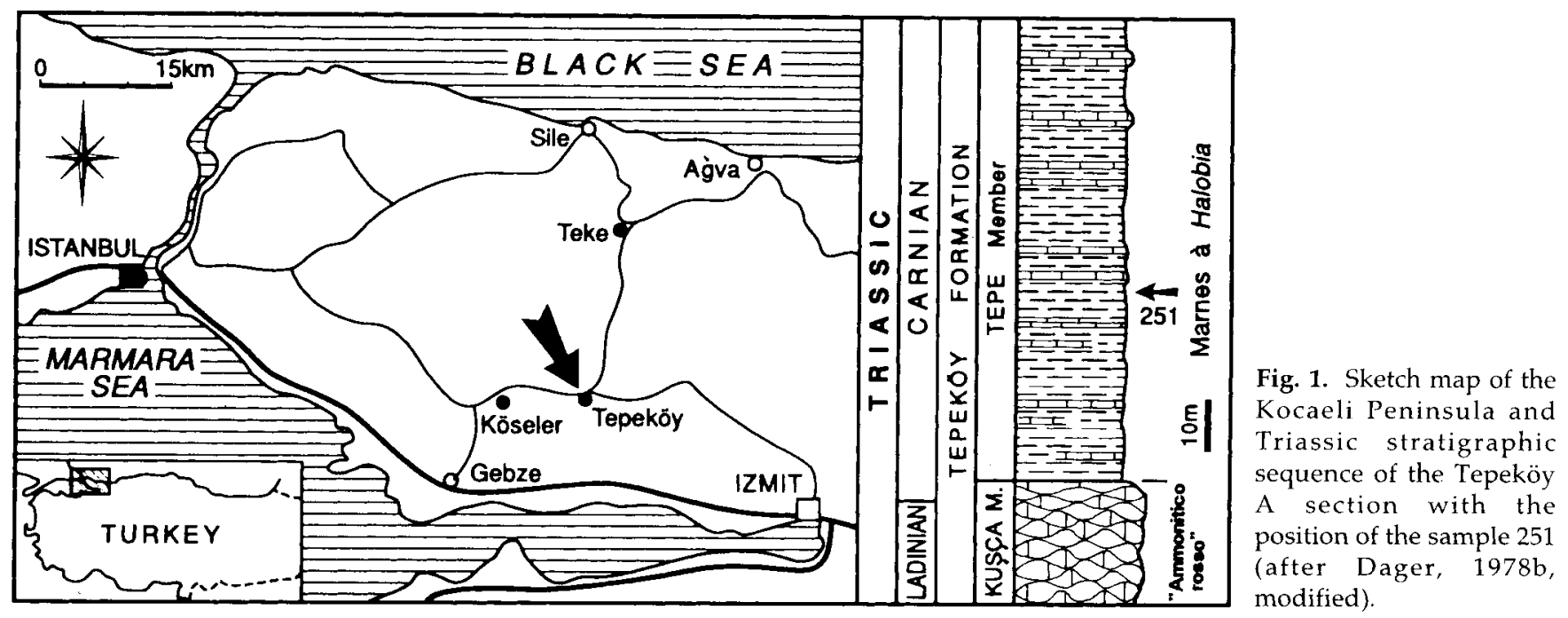

Holotype. Axial section, illustrated in pl.1, fig. 1; from thin section 251 (see Fig. 1).

Paratypes. Axial, equatorial and tangential sections, illustrated in Pl. 1, figs. 2-12, ?13.

Material. Sections in many planes from thin section 251, deposited at the Museum d'Histoire Naturelle in Geneva.

Type-locality. Section of Tepeköy A (Dager 1978b), north of village of Tepeköy, east of cemetery, Kocaeli Peninsula (Turkey).

Type-level. Green-grey marls with Halobia (H. bithynica); Piallina tethydis gen. et sp.nov. occurs in limestone beds intercalated within the marls (Fig. 1).

Description. Currently monotypic; description, therefore, as per genus.

Dimensions. Length of the test: $0.450 \mathrm{~mm}$, maximum diameter: $0.150 \mathrm{~mm}$.

Stratigraphical/geographical distribution. See under genus, above.

Association. P. tethydis is associated with Turriglomina carnica (Dager), Turriglomina cf. T. magna (Urosevic), Gsollbergella spiroloculiformis (Oravecz-Scheffer), Ophthalmidium spp., "Endothyra" ex group "E." obturata Brönnimann \& Zaninetti, Trochammina? sp., Duostominidae, Nodosariidae, encrusting foraminifera, etc.

Remarks on the Piallinidae Rettori \& Zaninetti, n.fam.

The description of the new family Piallinidae Rettori \& Zaninetti corresponds to that given for the presently unique genus Piallina. It differs from all the other families included by Loeblich \& Tappan (1987) in the Superfamily Verneuilinacea Cushman, in the type of coiling and in the chamber arrangement and also in the peculiar structure of the aperture.

The attribution to the Verneuilinacea is justified by the fact that the Family Tritaxiidae Plotrikova also presents a complex apertural structure. The Tritaxiidae, however, differs from the Piallinidae in the possession of an apertural tube, not observed in Piallina, and in having either a triserial chamber arrangement throughout or a triserial and biserial arrangement.

\section{ACKNOWLEDGEMENTS}

The present work is part of a project on Permian and Triassic biostratigraphy and sedimentology of the Tethyian realm, supported by the Fonds National Suisse de la Recherche scientifique (L. Z., project No.20-32368.91).

\section{Manuscript received February 1993 \\ Manuscript accepted April 1993}

\section{REFERENCES}

Assereto, R. 1972. Notes on the Anisian biostratigraphy of the Gebze Area (Kocaeli Peninsula, Turkey). Zeitschrift der Deutschen Geologischen Gesellschaft, 123, 435-444.

Assereto, R. 1974. Aegean and Bithynian: Proposal for two new Anisian Substages. Schriftenreihe der Erdwissenschaftlichen Kommision, Österreichische Akademi der Wissenschaften, Wien, 2, 23-39.

Dager, Z. 1977. Sur quelques Foraminiferes nouveaux du Trias de Kocaeli, Turquie. Ph.D. thesis, University of Geneva.

Dager, Z. 1978a. Sur quelques Foraminitères nouveaux du Trias de Kocaeli, Turquie. Notes du Laboratoire de Paléontologie de l'Universitè de Genève, 2, 21-25.

Dager, Z. 1978b. Les Foraminifères du Trias de la Péninsule de Kocaeli-Turquie. Notes du Laboratoire de Paléontologie de l'Universitè de Genève, 3, 23-71.

Gedik, I. 1975. Die Conodonten der Trias auf der KocaeliHalbinsel (Türkei). Palaeontographica, (A), 150, 99-160.

He Yan, 1990. Devonian-Triassic Stratigraphy and Palaeontology from Yushu Region of Qinghai, China. Part I. Nanjing

\section{Explanation of Plate 1}

Figs.1-12, ?13. Piallina tethydis Rettori \& Zaninetti gen. et sp.nov. Fig. 1. Holotype, thin section 251. Figs. 2-12, ?13. Paratypes, thin section 251. Several cross sections with different orientation. 


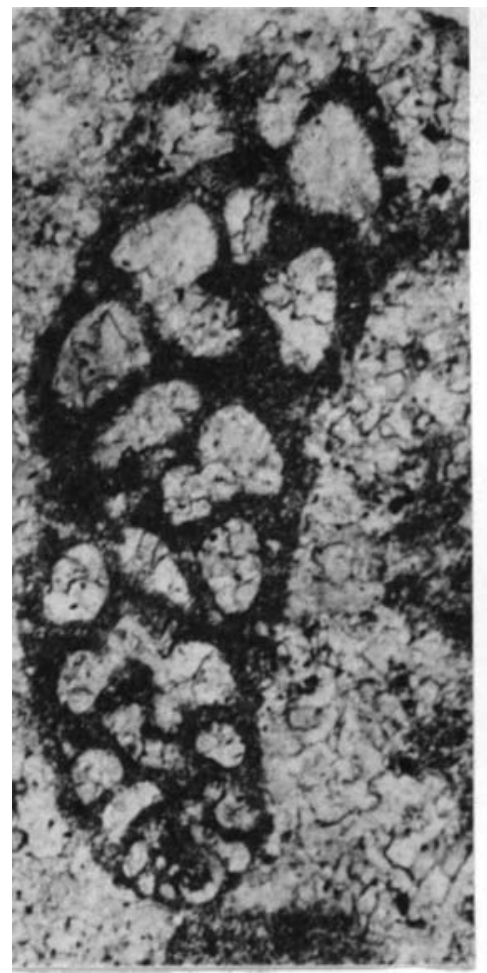

1

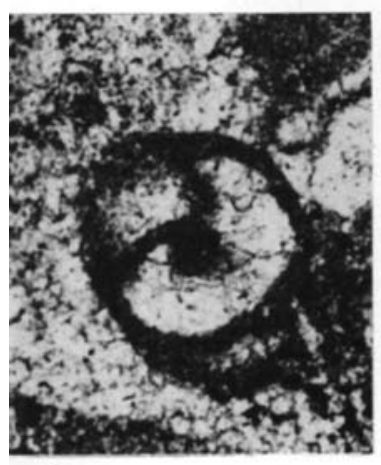

5

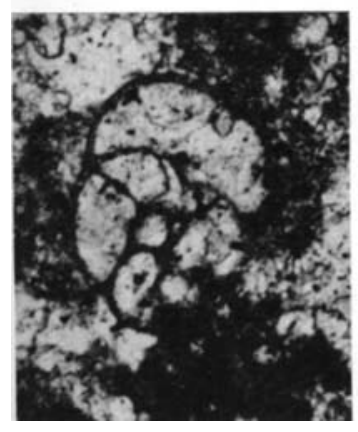

9
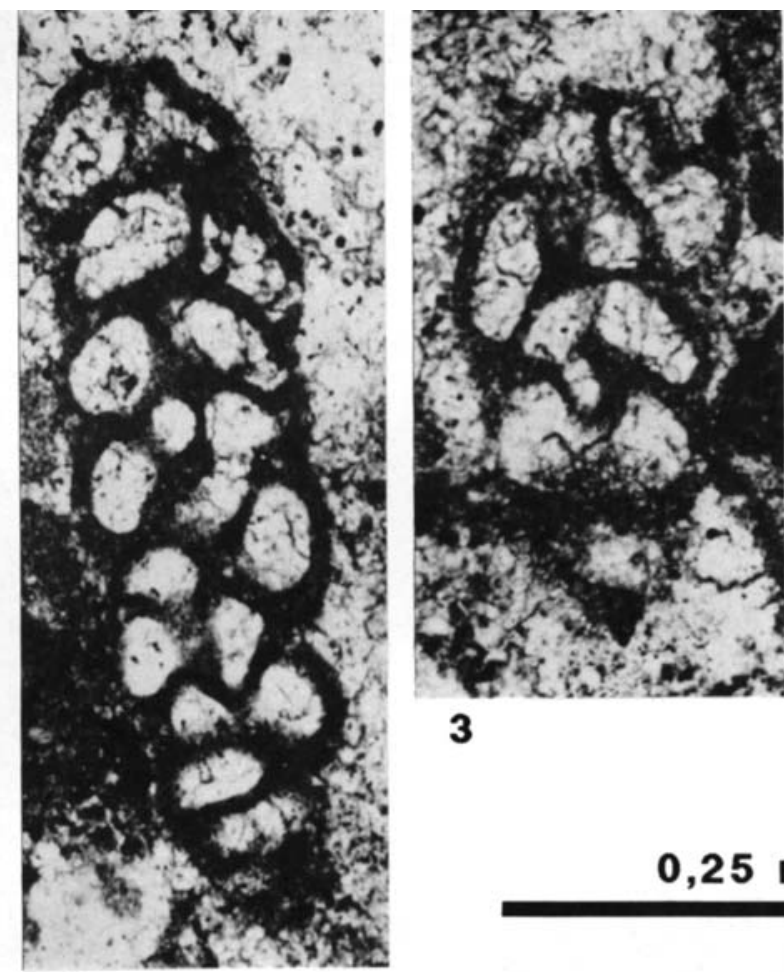

3

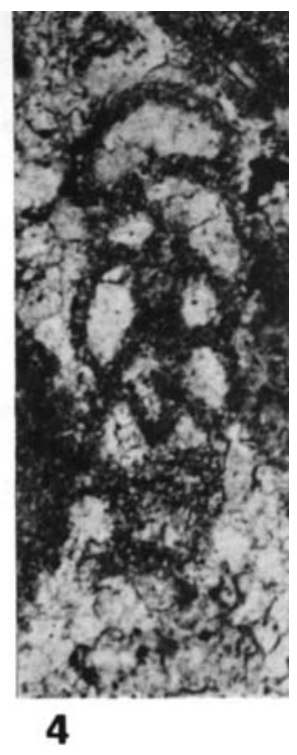

2

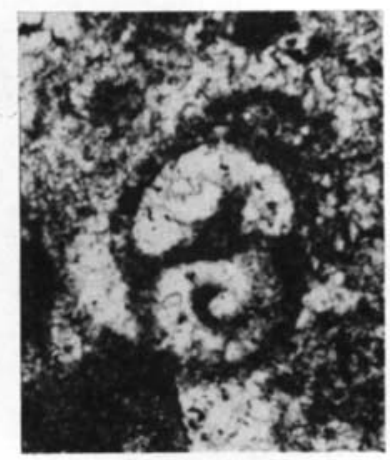

6

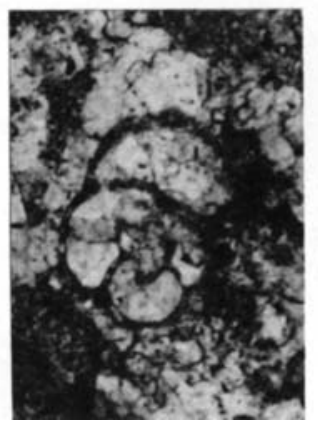

10

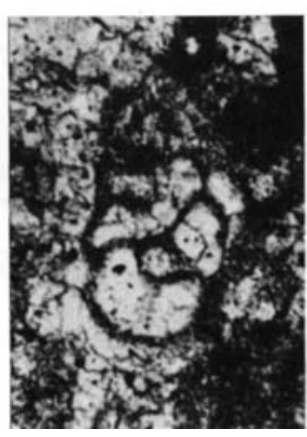

11

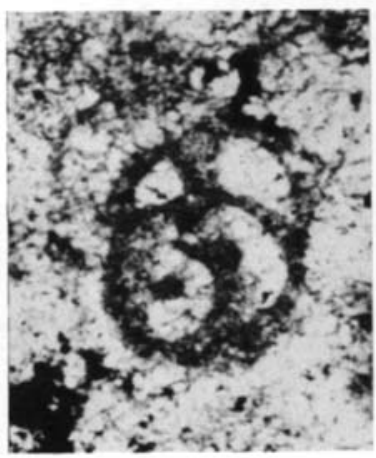

7

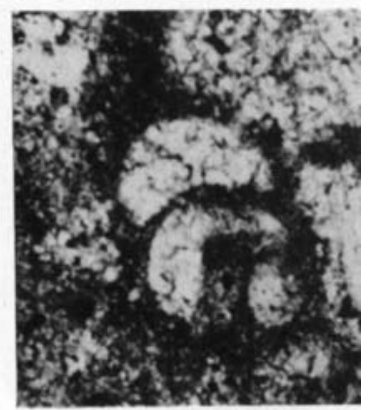

8

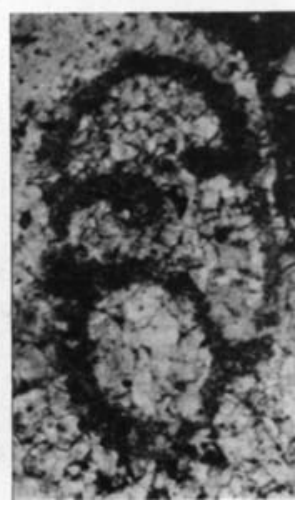

13 
University Press, pp. 59-96.

Loeblich, A.R. jr. \& Tappan, H. 1987. Foraminiferal Genera and their Classification. Van Nostrand Reinhold Company, New York.

Nicora, A. 1977. Lower Anisian platform-conodonts from the Tethys and Nevada: taxonomic and stratigraphic revision. Palaeontographica, (A), 157, 88-107.

Nicora, A. \& Premoli Silva, I. 1976. Benthonic Foraminifera for Early-Middle Triassic pelitic sequences from Chios (Greece) and Bithynia (Turkey) and correlations with Conodont and Ammonoid assemblages: preliminary note. Special Publication of the 1st International Symposium on Benthonic Foraminifera of Continental margins. Part B. Palaeoecology and Biostratigraphy, pp. 487-499.

Özdemir, Ü, Talay, G. \& Yurtsever, A. 1973. Kocaeli Triyasi Projesi "Kocaeli Triyasinin Biyostratigrafik Etüdü". Yil Baskini, 50, 1-15.
Oravecz-Scheffer, A. 1987. Triassic foraminifers of the Transdanubian Central Range. Geologica Hungarica, (Series Palaeontologica), 50, 1-331.

Yurttas-Özdemir, G. 1971. Kocaeli yarimadasi, Tepeköy Triyasi makrofaunasi ve biyostratigrafisi. Maden Tetkik ve Arama Enstitüsü Dergisi, 77, 57-98.

Yurttas-Özdemir, G. 1972. Makrofauna und Biostratigraphie der Tepeköy-Trias Halbinsel Kocaeli. Zeitschrift der Deutschen Geologischen Gesellschaft, 123, 433-434.

Yurttas-Özdemir, G. 1973. Güber den Schieferton mit Halobia der Halbinsel Kocaeli. Bulletin of the Mineral Research and Exploration Institute of Turkey, 80, 43-49.

Zaninetti, L. \& Dager, Z. 1978. Biostratigraphie intégrée et paléoécologie du Trias de la péninsule de Kocaeli (Turquie). Eclogae Geologicae Helvetiae, 71, 85-104. 